\title{
Ecological distribution of Penaeus schmitti (Dendrobranchiata: Penaeidae) juveniles and adults on the southern coast of São Paulo state, Brazil
}

João G. Barioto, Gilson Stanski, Raphael C. Grabowski, Rogerio C. Costa \& Antonio L. Castilho

To cite this article: João G. Barioto, Gilson Stanski, Raphael C. Grabowski, Rogerio C. Costa \& Antonio L. Castilho (2017) Ecological distribution of Penaeus schmitti (Dendrobranchiata:

Penaeidae) juveniles and adults on the southern coast of São Paulo state, Brazil, Marine Biology Research, 13:6, 693-703, DOI: 10.1080/17451000.2017.1287923

To link to this article: https://doi.org/10.1080/17451000.2017.1287923

曲 Published online: 09 May 2017.

Submit your article to this journal $\pi$

Џ Article views: 45

View Crossmark data $₫$

Citing articles: 2 View citing articles $\llbracket$ 


\title{
Ecological distribution of Penaeus schmitti (Dendrobranchiata: Penaeidae) juveniles and adults on the southern coast of São Paulo state, Brazil
}

\author{
João G. Barioto ${ }^{a}$, Gilson Stanski ${ }^{a}$, Raphael C. Grabowski ${ }^{a}$, Rogerio C. Costa ${ }^{b}$ and Antonio L. Castilho ${ }^{a}$ \\ ${ }^{a}$ Instituto de Biociências de Botucatu, NEBECC - Núcleo de Estudos em Biologia, Ecologia e Cultivo de Crustáceos, Universidade Estadual \\ Paulista, Botucatu, Brazil; ${ }^{\text {b}}$ Departamento de Ciências Biológicas, Faculdade de Ciências, LABCAM - Laboratório de Biologia de Camarões \\ Marinhos e de Água Doce, Universidade Estadual Paulista, Bauru, Brazil
}

\begin{abstract}
This study aimed to describe the ecological distribution and the effects of environmental factor oscillation on the life cycle of Penaeus schmitti along the coastal area of Cananéia, southern São Paulo state, Brazil. Shrimp and environmental factors were sampled monthly from July 2012 to May 2014 at seven sampling stations covering both estuarine and marine environments, using a shrimp fishing boat. A total of 273 juveniles and 829 adults were sampled, and there were significant differences in body size (carapace length $-\mathrm{CL}$ ) throughout the seasons (ANOVA). Smaller animals were observed in the summers of 2013 and 2014 and at sites closer to the coast, which are under estuarine influence. Adults were observed mostly in autumn and in deeper regions. We detected a positive relationship between the abundance of juveniles and the bottom water temperature and between the abundance of adults and the water salinity (canonical correspondence analysis). The presence of smaller individuals in the estuarine environment demonstrates the importance of the estuaries in this species' ontogeny, mainly concerning their protection, since this environment has physical (depth) and physiological (salinity) barriers to their predators. Furthermore, we could clearly observe the plasticity of juveniles in relation to environmental factors. In contrast, adults were less tolerant to the variation in environmental factors, mainly water salinity, which was a limiting factor of their distribution. Seasonal differences in body size could be directly associated to this species' life cycle and characterized by trophic and reproductive migratory activities between the estuarine and oceanic regions.
\end{abstract}

\section{ARTICLE HISTORY}

Received 28 June 2016

Accepted 24 January 2017

Published online 9 May 2017

\section{RESPONSIBLE EDITOR}

Francesc Maynou

\section{KEYWORDS}

Habitat selection; nursery grounds; Penaeoidea; population dynamics

\section{Introduction}

In southern and south-eastern Brazil, shrimp fishery is mainly aimed at stocks of Penaeus brasiliensis Latreille, 1817, Penaeus paulensis Perez Farfante, 1967, Xiphopenaeus kroyeri (Heller, 1862) and Penaeus schmitti Burkenroad, 1936 ( $D^{\prime}$ Incao et al. 2002); the last species is considered the fourth most important species in terms of fishery biomass in Brazil (Caparelli et al. 2012). However, due to the increase in fishing activities in the last few decades, these resources are facing an overfishing situation caused by indiscriminate exploitation, which can compromise or even cause a collapse in the abundance of exploited species, such as $P$. schmitti (Pérez et al. 2001; Pauly et al. 2002).

Fishing represents the main economic activity in Cananéia, being the subsistence of hundreds of families and offering employment in shrimp processing and commercialization, trading of fishing supplies, and boat repair. Annual fishing productivity is high; in 2012 the area was considered the second most productive fishing region in São Paulo state, with shrimp as the main marine resource (Mendonça 2015).

Penaeus schmitti, like the majority of the penaeid shrimps, spends most of its life cycle in contact with or burrowed in the seafloor for energy saving or protection against predators; this behaviour suggests a fundamental importance of the spatial distribution of the species (Dall et al. 1990; Sanchez 1997; da Costa \& Fransozo 2004). Additionally, drastic changes in water temperature and salinity can directly or indirectly affect the abundance and even the presence of a species in a given area (Stanley 1984; Dall et al. 1990; Castilho et al. 2008). These features have an impact on shrimp metabolism and alter growth and reproduction rates (Bauer \& Lin 1994; Hartnoll 2001).

Over the last few years, some studies on the ecology and population dynamics of $P$. schmitti have been carried out along the Brazilian coast, including the

CONTACT João G. Barioto barioto@ibb.unesp.br Departamento de Zoologia, Instituto de Biociências, Universidade Estadual Paulista, Distrito Rubião Junior s/n, Botucatu, São Paulo, 18618-689, Brazil

(c) 2017 Informa UK Limited, trading as Taylor \& Francis Group 
investigation of its life cycle in Pernambuco (Northeastern coast of Brazil; Coelho \& Santos 1994) and its ecological aspects in the estuary and bay regions of Ubatuba (south-eastern coast of Brazil; Caparelli et al. 2012). Additionally, the movement of post-larvae into the estuarine-lagoon region of Cananéia (south-eastern coast of São Paulo state) was reported by ChagasSoares et al. (1995), which is the same region addressed in our study. There have been no studies on the ecological distribution of juveniles and adults of $P$. schmitti from the southern coast of São Paulo state. Thus, this study represents pioneering work on this subject.

Based on this scenario, this study aimed to describe the spatio-temporal distribution and the effect of the oscillation of environmental factors on the life cycle of $P$. schmitti during the juvenile and adult phases in the coastal and estuarine areas of Cananéia, southern coast of São Paulo state, Brazil. Additionally, we analysed the efficiency of the fisheries closure period (from 1 March to 31 May) in protecting the species' recruitment period.

\section{Material and methods}

\section{Study area}

Cananéia is located in the southern area of São Paulo state and is characterized by its complex lagoon basin. The basin is strongly influenced by fresh water coming from the Ribeira lguape River and is composed of four big islands: Iguape Island (in the north), Comprida Island (in the centre) and Cananéia and Cardoso Islands (in the southern portion) (Bergamo 2000). The estuarine-lagoon system of Cananéia-lguape has two main connections to the ocean: Mar Pequeno and Barra de Icapara in the north, and Mar de Cananéia and Mar de Cubatão in the south (Mendonça 2007) (Figure 1).

The Brazilian coast is influenced by many water masses, such as Tropical Water (TW) $\left(\mathrm{T}>20^{\circ} \mathrm{C}, \mathrm{S}>36\right)$, Coastal Water (CW) $\left(\mathrm{T}>20^{\circ} \mathrm{C}, \mathrm{S}<36\right)$ and South Atlantic Central Water (SACW) $\left(\mathrm{T}<18^{\circ} \mathrm{C}, \mathrm{S}<36\right)$ (Matsuura 1986).

The studied area is therefore of ecological importance, with high environmental diversification and faunal and floral biodiversity (Diegues 1987). Cananéia does not have well-developed industrial activities, and thus, the county's financial profit is based on fishing tourism (Diegues 2002; Mendonça 2007).

\section{Sample collection}

Samples were collected monthly from July 2012 to May 2014 at seven sampling stations along the coast of
Cananéia, in the southern region of São Paulo state. Trawls lasting 30 minutes were performed in the complex Cananéia-Iguape estuarine-lagoon system and the adjacent oceanic area using a shrimp boat equipped with double-rig nets (mesh size $20 \mathrm{~mm}$ and $15 \mathrm{~mm}$ in the cod end) to collect the biological material. Sampling stations were determined with a global positioning system (GPS), and the depths were identified by nautical charts and monitored using a Eureka multiparameter probe. The first four sampling stations were in the oceanic area (I, II and III within the $10-15 \mathrm{~m}$ isobaths, and IV within the $5-10 \mathrm{~m}$ isobaths), and the other three stations were in the estuarine zone (Mar Pequeno) (V, VI and VII within the 5-10 m isobaths) between Cananéia and Comprida Islands, which is influenced by the freshwater inflow from the Ribeira Iguape River (Besnard 1950; Garcia et al. 2016) (Figure 1).

In the laboratory, shrimp were identified according to Costa et al. (2003) and quantified. It is noteworthy that, due to adverse oceanic conditions, the March 2013 sampling was only performed at stations V, VI and VII (for more details see Garcia et al. 2016). The reproductive condition of each shrimp was determined by macroscopic examination of the terminal ampoule in males and ovaries in females. The sexual maturity of penaeid males is usually indicated by the fusion of the petasmal lobes (gonadal endopods), whereas juvenile males have separate petasmal lobes (Boschi 1989; Bauer \& Rivera Vega 1992). The maturity of adult males was classified according to the development of spermatophores in the terminal ampoule (ejaculatory duct). When the spermatophores were not visible by macroscopic observation, the adult male was classified as lacking spermatophores (M-1); if spermatophores were visible and occupied part of (developing) or all of (developed) the terminal ampoule, males were classified as spermatophore-bearing males (M-2) (Castilho et al. 2015b).

Maturity of the ovaries was determined based on the colour and volume of this organ within the carapace of female. Juvenile females had very thin ovaries lacking any colouration, while adult females had thick ovaries varying in colour from opaque white to olive green. Ovaries in adult females were classified as spent (Stage I) if they were opaque white in colour and thicker than the juvenile ovaries, as developing (Stage II) if they were light green, or as developed (near spawning) (Stage III) if they were green to olive green (Stage I = F-1; Stages II + III = F-2) (Bauer \& Rivera Vega 1992; Nakagaki \& Negreiros-Fransozo 1998). 


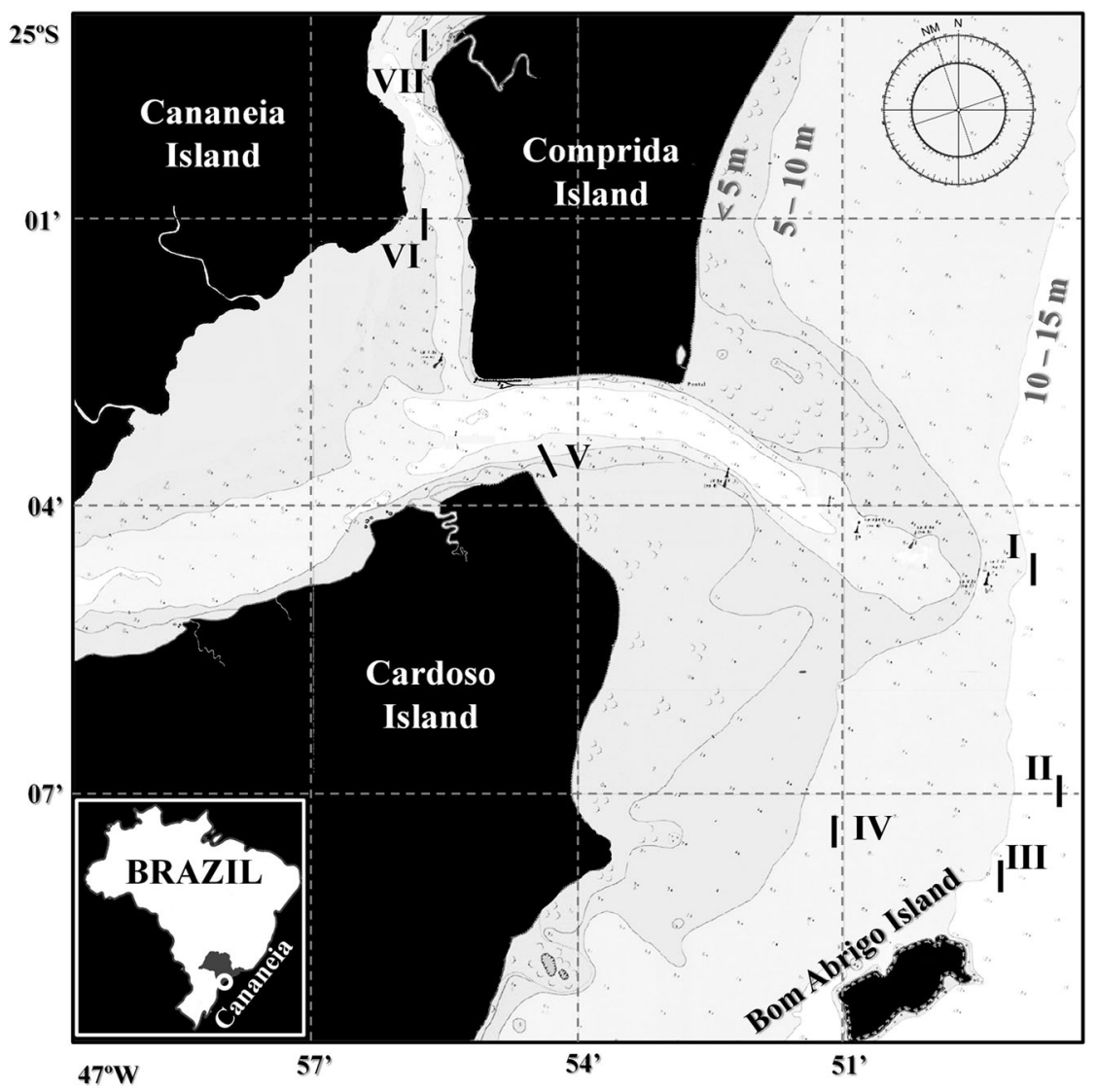

Figure 1. Cananéia region showing sampling stations in the adjacent oceanic area (I, II, III and IV) and estuarine area (Mar Pequeno - V, VI and VII). Source: Garcia et al. (2016).

\section{Environmental factors}

The environmental parameters of water salinity and temperature were measured monthly with a Eureka (Manta model 2-4.0) multiparameter probe at each of the seven sampling stations jointly with the biological samples. Sediment samples were collected by season in the southern hemisphere (summer: January to March, etc.). The methodology used for the subsequent analysis was based on the studies of Hakanson \& Jansson (1983) and Tucker (1988).

Sediment samples were obtained with a Petersen grab at each of the seven sampling stations and frozen until laboratory analysis could be carried out. In the laboratory, the samples were oven dried at $70^{\circ}$ $\mathrm{C}$ for 72 hours. Subsequently, $10 \mathrm{~g}$ subsamples were used for organic matter analysis and $100 \mathrm{~g}$ subsamples for granulometric determination. The $10 \mathrm{~g}$ subsamples were placed in porcelain containers and weighed for combustion in a muffle furnace at $500^{\circ} \mathrm{C}$ for 3 hours to burn off all the organic matter. After combustion, the porcelain containers were weighed again, and the difference between the initial and final weight corresponded to the percentage of organic matter (Tucker 1988).
The $100 \mathrm{~g}$ subsamples were treated for approximately 10 minutes in $250 \mathrm{ml}$ of a $0.2 \mathrm{~N} \mathrm{NaOH}$ solution in distilled water to facilitate the separation of silt and clay from the other grains. Then, the subsamples were rinsed through a $0.0625-\mathrm{mm}$ sieve to eliminate silt and clay. After that, the subsamples were dried again at $60^{\circ}$ $C$ for 24 hours and subsequently sieved through a sequence of six sieves, which resulted in the following granulometric classes: gravel $(>2 \mathrm{~mm})$, very coarse sand $(1-2 \mathrm{~mm})$, coarse sand $(0.5-1 \mathrm{~mm})$, medium sand $(0.25-0.5 \mathrm{~mm})$, fine sand $(0.125-0.25 \mathrm{~mm})$ and very fine sand $(0.0625-0.125 \mathrm{~mm}$ ) (Suguio 1973; Hakanson \& Jansson 1983).

Grain size was expressed on the phi scale $(\Phi)$, which corresponds to the measure of central tendency for sediment samples (Suguio 1973). The granulometric fraction most frequently found in the sediment sample was determined by cumulative curves according to Wentworth (1922) using the formula $M d=\left(\Phi_{16}\right.$ $\left.+\Phi_{50}+\Phi_{84}\right) / 3$. The classes of phi were converted into granulometric fractions using $-\log _{2} \mathrm{~d}$, obtaining the following relation: $-1=\Phi<0$ (gravel), $0=\Phi<1$ (coarse sand), $1=\Phi<2$ (medium sand), $2=\Phi<3$ (fine sand), $3=\Phi<4$ (very fine sand) and $\Phi \geq 4$ (silt + clay). 


\section{Statistical analysis}

Tests for normality (Shapiro-Wilk's) and homoscedasticity (Levene's) were performed as a prerequisite for the choice of the statistical test. When the data were not normally distributed, they were logarithmically transformed $(\log x+1)$.

Analysis of variance (ANOVA) and a post hoc test (Tukey's) were used to determine significant differences between population abundances by season.

Shrimp were separated into the five demographic categories: juvenile (immature males and females), males with terminal ampoule in Stage I $(\mathrm{M}-1)$ and Stage II (M-2), females with ovaries in Stage I (F-1), and reproductive females (females with ovaries in Stages II and III pooled together, F-2). The relationship between each of these demographic categories and the bottom water temperature, salinity, phi, organic matter content and abundance was assessed using canonical correspondence analysis (CCA, $a=0.05)$ in R software (R Development Core Team 2008). This analysis computes a combination of scores for the dataset with
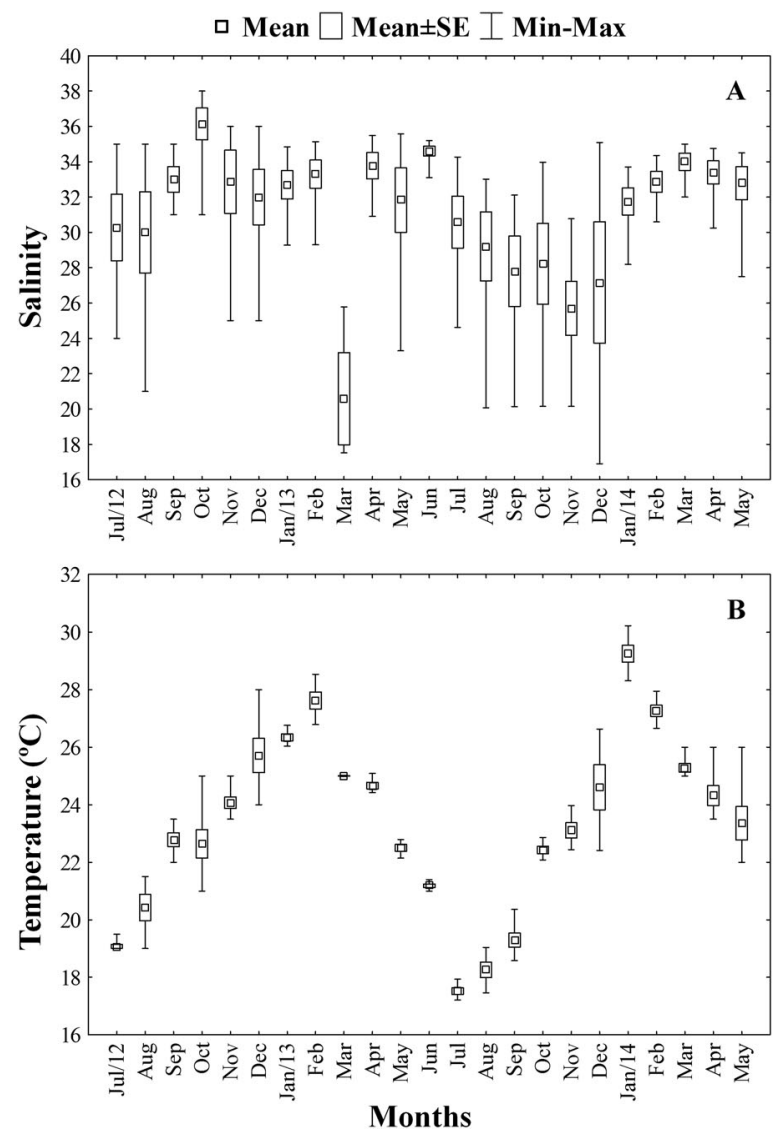

Figure 2. Monthly variation of bottom water features (salinity $=\mathrm{A}$ and temperature $=\mathrm{B}$ ) recorded in Cananéia, São Paulo state, from July 2012 to May 2014. SE: standard error; Min: minimum value; and Max: Maximum value. maximum linear correlations, showing the highest explanation levels of the variance in the dataset. To interpret this ordination technique, the canonical coefficients were used, which permits relating variation in the abundance of the different demographic categories to variation in environmental parameters (Ter Braak 1986). The statistical significances of the eigenvalues and the demographic categories vs environment correlations were evaluated by randomization (Monte Carlo tests), using 1000 permutations. For CCA, the data were log-transformed prior to analysis (Zar 1999).

The size at which $50 \%$ of the population is considered reproductively active (CL50\%) was determined using the proportion of juvenile and adult individuals in the size class of $2.0 \mathrm{~mm}$ in carapace length. The procedure used here to estimate sexual maturity was based on fitting the sigmoid logistic curve, using the equation $y=1 /(1+e[-r(C L-C L 50)])$, where $y$ is the estimated proportion of adult shrimp, CL50\% is the carapace size at the onset of sexual maturity, and $r$ is the coefficient for the slope of the logistic curve (Castilho et al. 2015a).
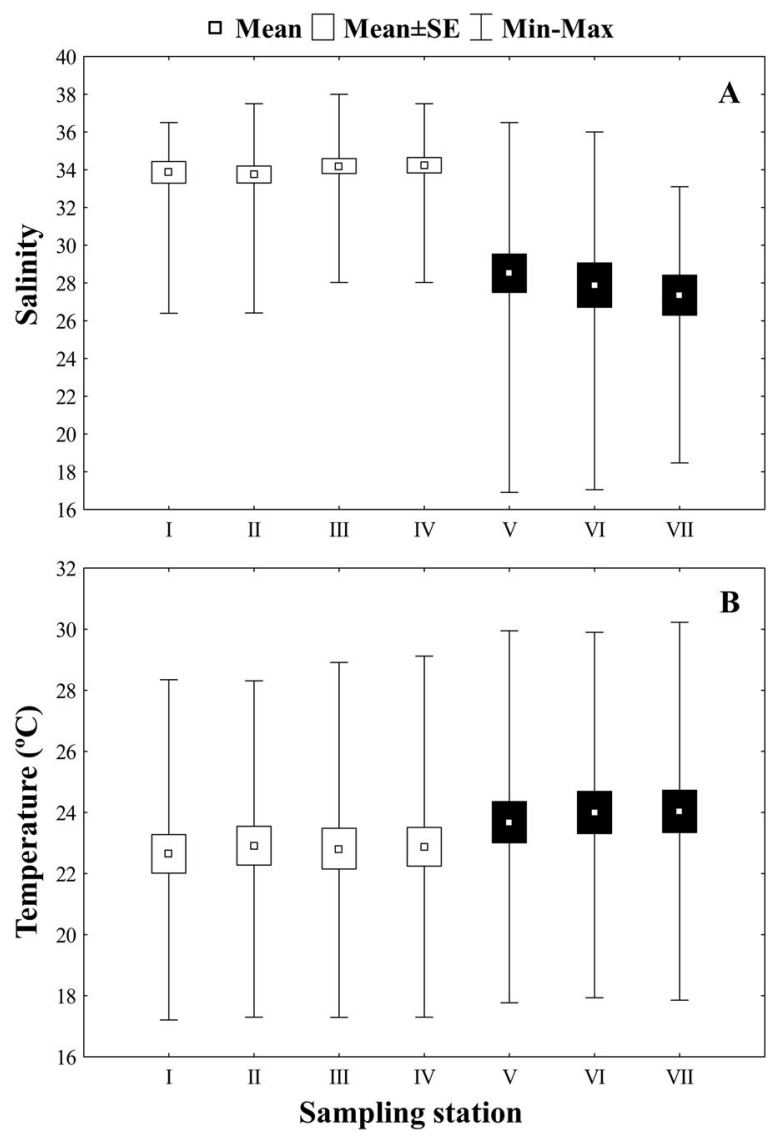

Figure 3. Bathymetric variation of bottom water features (salinity $=$ A and temperature $=B$ ) recorded in Cananéia, São Paulo state, from July 2012 to May 2014. SE: standard error; Min: minimum value; and Max: Maximum value. Black filled boxes represent the estuarine zone. 


\section{Results}

\section{Environmental factors}

Within the studied period, the environmental factors showed greatest variation in bottom water salinity and temperature values. The highest salinity values were observed in October 2012, June 2013 and March 2014 (>34), while the lowest ones were observed in March 2013 (20.6) and November 2013 (25.7) (Figure 2). Sampling stations IV and VII showed the highest (34.2) and lowest (27.3) average values for this parameter, respectively (Figure 3 ).

In July 2012 and July 2013, we observed the lowest values $\left(<19^{\circ} \mathrm{C}\right)$ of bottom water temperature, while in February 2013 and January 2014, we recorded the highest means $\left(>27^{\circ} \mathrm{C}\right.$ ) of this parameter (Figure 2), corresponding to winter and summer, respectively. We did not observe drastic differences in spatial variation of the bottom water temperature. However, there was a tendency of decreasing temperature with increasing salinity (Figure 3 ).

The organic matter content varied from 2 to $5 \%$ throughout the seasons of the year, with a lower concentration in winter 2013 and a higher one in spring 2012 (Table I). Sampling station VI presented higher percentages of this feature $(5.98 \%)$ and showed the highest phi value (4.76), characterizing the station as predominantly composed of silt and clay. The lowest average value phi was recorded at sampling station VI (2.79) (Table II).

\section{Abundance and distribution}

A total of 1102 individuals of Penaeus schmitti (273 juveniles and 829 adults) were sampled. The CL50\% was $26.7 \mathrm{~mm}$ for females and $24.7 \mathrm{~mm}$ for males. Among all adult individuals, 388 were males (46.8\%) and 441 were females (53.2\%), while of the juveniles, 157 were females $(57.5 \%)$ and 116 were males (42.5\%). A higher abundance of juveniles was observed

Table I. Mean values \pm standard deviation for sediment features (grain size (Phi)) and organic matter content (OM) for all seasons at Cananéia, São Paulo state, from July 2012 to May 2014.

\begin{tabular}{lcc}
\hline Season of the year & Phi $(\varphi)$ & OM (\%) \\
\hline winter/12 & $3.12 \pm 0.62$ & $3.11 \pm 1.33$ \\
spring/12 & $3.92 \pm 1.11$ & $4.93 \pm 5.44$ \\
summer/13 & $3.30 \pm 1.31$ & $3.98 \pm 4.58$ \\
autumn/13 & $3.80 \pm 0.86$ & $3.99 \pm 2.79$ \\
winter/13 & $3.54 \pm 1.08$ & $2.48 \pm 2.28$ \\
spring/13 & $3.59 \pm 1.04$ & $3.22 \pm 1.17$ \\
summer/14 & $3.51 \pm 0.76$ & $4.08 \pm 3.09$ \\
autumn/14 & $3.76 \pm 1.39$ & $3.82 \pm 3.80$ \\
\hline
\end{tabular}

in March 2014 and June 2013, while a higher abundance of adult individuals was recorded from February to April 2014 and in June 2013 (summer and autumn, respectively) (Figure 4).

Juveniles were captured mostly at sampling station IV, with a greater rate of occurrence at stations influenced by the estuarine environment, while adults were found mostly at sampling station II, with greater occurrence in the marine environment (Figure 5). We observed a difference in the temporal distribution of juveniles and adults between summer and other seasons (ANOVA, $P=0.0001 ; F=51.57$ ) (Figure 6). Smaller individuals were sampled at sampling stations closer to the coast, which are subject to estuarine influence (stations V, VI and VII) (Figure 7) and therefore presented salinity values lower than 28 during the sampling months. The standardization of capture per unit of effort (CPUE) revealed differences in the abundance of juveniles and adults. Adults presented a higher abundance at salinity classes from 33 to 36 and were sampled at all temperature values, while juveniles showed a higher abundance at higher temperature values (Figure 8). Adults occupied a thinner substrate in comparison to juveniles, with organic matter amounts between 6 and 9\% (Figure 8).

The CCA used to test the relationship between environmental variables and the abundance of the different demographic categories of $P$. schmitti explained $67 \%$ of the variance in our dataset (Figure 9). Only water temperature (CCA, $P=0.0009)$ and salinity $(P=0.052)$ showed correlations with shrimp abundance. Highlighted on the first axis of the CCA (45\%) is a positive correlation between the abundance of juveniles vs. water temperature and salinity vs. adults (F-1, F2, M-1 and M-2) (Table III, Figure 9).

\section{Discussion}

Our results show a different distribution between juveniles and adults of Penaeus schmitti between months and sampling stations, with a greater

Table II. Mean values \pm standard deviation for sediment features (grain size (Phi)) and organic matter content (OM) for the sampling stations located at Cananéia, São Paulo state, from July 2012 to May 2014.

\begin{tabular}{lccc}
\hline & Sampling station & Phi $\varphi$ & OM (\%) \\
\hline Oceanic area & I & $3.75 \pm 0.96$ & $3.46 \pm 3.05$ \\
& II & $3.59 \pm 1.01$ & $3.92 \pm 3.06$ \\
Estuarine zone & III & $3.55 \pm 0.95$ & $3.13 \pm 3.16$ \\
& IV & $4.76 \pm 0.96$ & $5.98 \pm 3.07$ \\
& V & $3.49 \pm 1.02$ & $3.20 \pm 3.03$ \\
& VI & $2.79 \pm 1.03$ & $2.55 \pm 3.24$ \\
VII & $3.24 \pm 1.03$ & $3.00 \pm 3.24$ \\
\hline
\end{tabular}




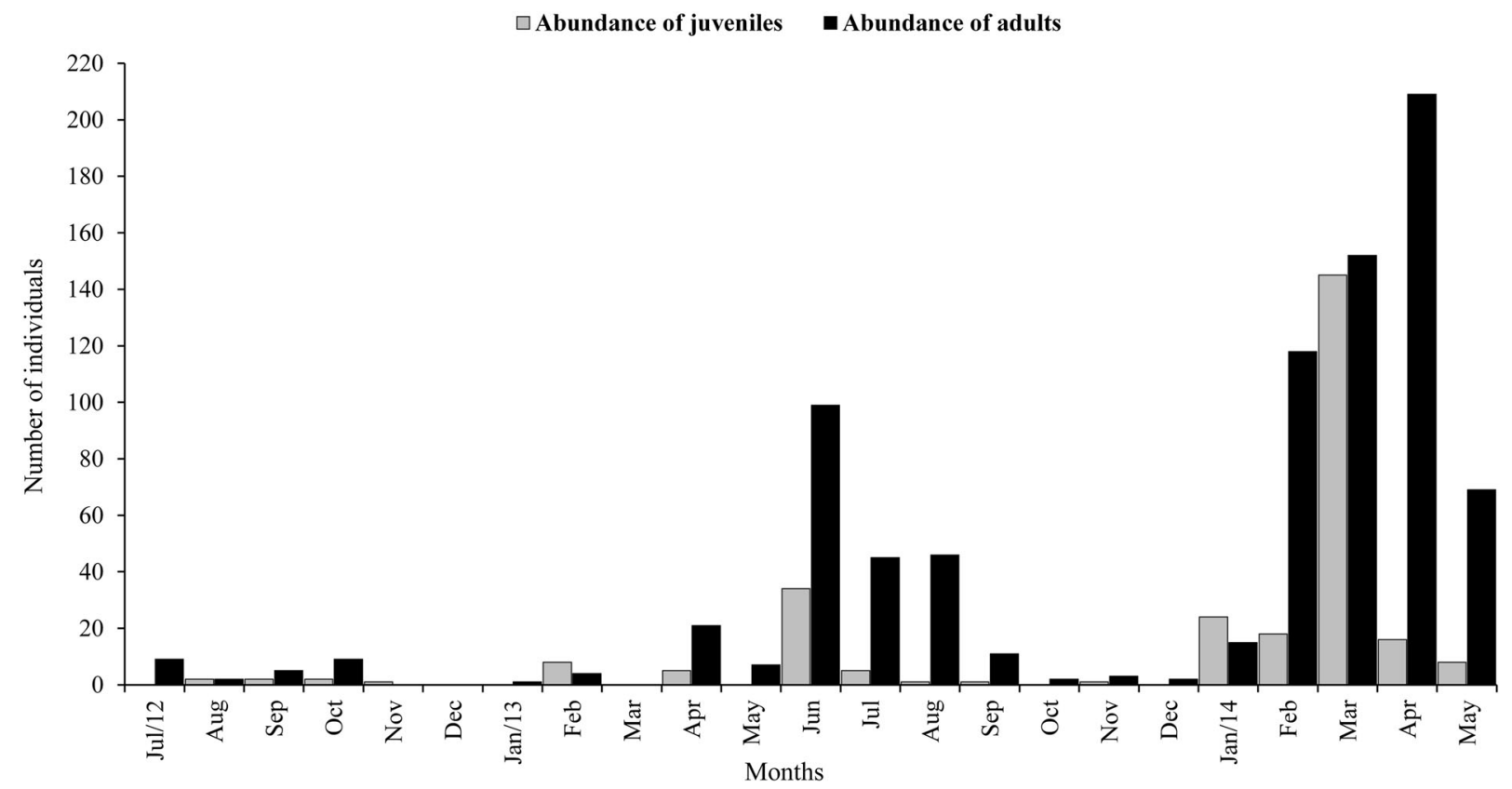

Figure 4. Monthly variation of the abundance of juveniles (grey bars) and adults (black bars) of Litopenaeus schmitti, sampled in the coastal area of Cananéia, São Paulo state, from July 2012 to May 2014.

abundance of juveniles caught in the sampling stations with estuarine influence throughout the sampling period. This suggests that this species completes its life cycle in Cananéia, and this region can therefore be considered a nursery ground for $P$. schmitti.

It should be highlighted that the low selectivity of the sampling gear used in this study made it impossible for smaller animals to escape; we therefore theoretically sampled all animals found in the trawling area (including the entire size range). Thus, the different sizes of the individuals observed when comparing the seasons can be related to their life cycle and characterized by migratory movements of trophic and reproductive natures. This activity occurs in the estuarine zone, where the advanced stages (post-larvae and juveniles) remain temporarily, maturing quickly due to the high food supply in these natural breeding grounds, and in the oceanic zone where the species ends its ontogenetic development and reproduces (Dura 1985). These results can also be considered evidence for including the species in life cycle type II, as proposed by Dall et al. (1990), in which post-larvae migrate to

$\square$ Abundance of juveniles

abundance of adults

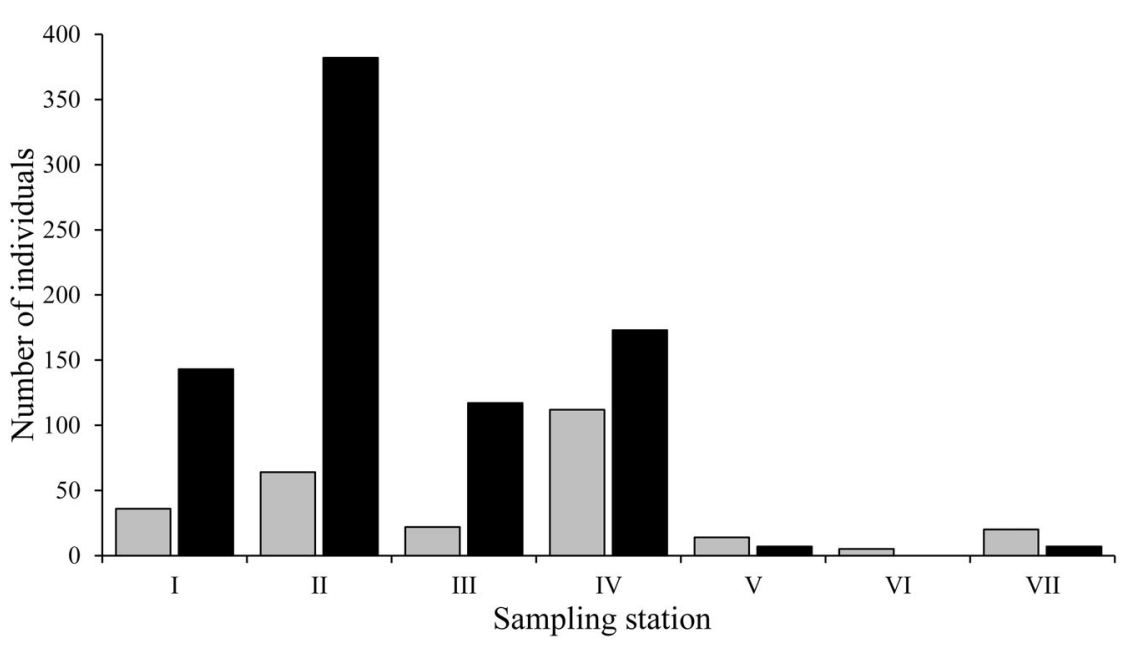

Figure 5. Spatial variation of the abundance of juveniles and adults of Litopenaeus schmitti, sampled in the coastal area of Cananéia, São Paulo state, from July 2012 to May 2014. 


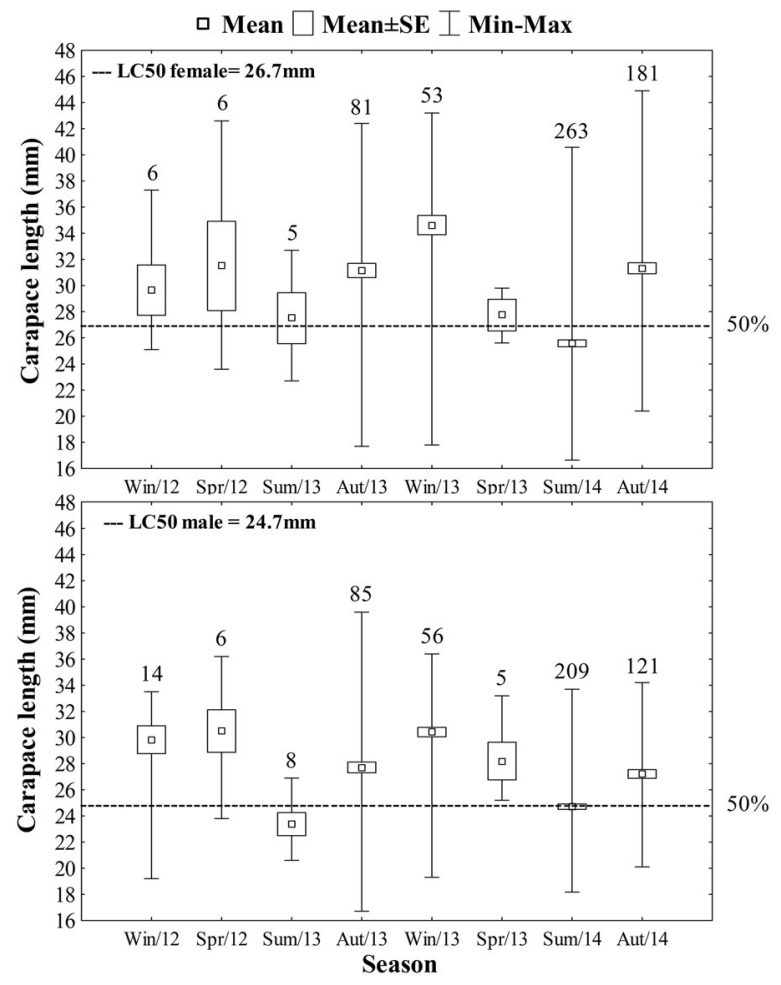

Figure 6. Variation of carapace length for females and males of Litopenaeus schmitti in the different seasons, sampled in the coastal area of Cananéia, São Paulo state, from July 2012 to May 2014. SE: standard error; Min: minimum value; Max: Maximum value; dotted lines: size in which $50 \%$ of the population is considered reproductively active (LC50\%); and numbers above boxes: abundance of individuals.

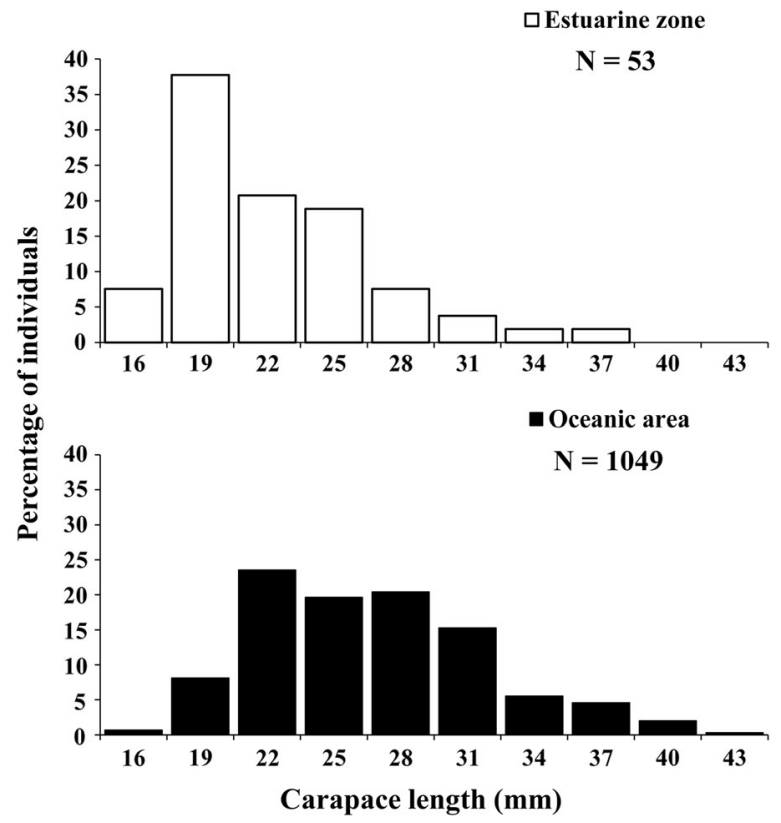

Figure 7. Variation of carapace length for individuals of Litopenaeus schmitti for the sampling stations in the estuarine zone (sampling stations V, VI, VII) and oceanic area (sampling stations I, II, III, IV) from Cananéia, São Paulo state, from July 2012 to May 2014.
Table III. Litopenaeus schmitti. Results of the canonical correspondence analysis (CCA) ordination for the first two canonical axes with demographic category and environmental variable data for bottom temperature and bottom salinity. Phi = measure of central tendency of the sediment; $\mathrm{OM}=$ organic matter; males with terminal ampoule in Stage I (M-1) and Stage II (M-2); and females with ovaries in Stage I (F-1) and Stages II + III (F-2). P= significance based on 1000 permutations (Monte Carlo test).

\begin{tabular}{lrrrr}
\hline & \multicolumn{2}{c}{ Canonical } & & \\
\cline { 2 - 3 } & coefficients & & $r^{2}$ & $P$ \\
\cline { 2 - 3 } Exis 1 & Axis 2 & & \\
Environmental variables & & & & \\
Salinity & 0.928 & -0.374 & 0.205 & 0.001 \\
Phi & -0.734 & -0.680 & 0.087 & 0.053 \\
OM & -0.874 & 0.486 & 0.010 & 0.714 \\
Demographic categories & -0.392 & -0.920 & 0.000 & 0.996 \\
Juvenile & & & & \\
M-1 & 0.733 & -0.680 & 0.276 & 0.001 \\
M-2 & -0.743 & -0.669 & 0.133 & 0.020 \\
F-1 & -0.079 & -0.997 & 0.432 & 0.001 \\
F-2 & -0.420 & -0.907 & 0.290 & 0.001 \\
\hline
\end{tabular}

the estuary, remaining there until they reach the juvenile or sub-adult stages and then migrate to the open sea.

This biological feature implies that smaller individuals occur in summer when compared with the ones observed in autumn, and the abundance in summer is a result of the reproductive output of females in spring. This result corroborates the findings of Santos et al. (2008) for the same species in Baixada Santista, Brazil. This is true mainly for sites that show welldefined seasons of the year, such as Cananéia, where spring is characterized by increased temperatures, high rainfall rates and increases in organic matter content (Kutner 1972). This set of environmental features in spring leads to an abrupt rise in primary productivity in the estuarine zone, mainly due to the increased chlorophyll content and the consequent increase in phytoplankton and zooplankton abundance; the resulting environment is ecologically favourable for the survival of larvae and the development of a new generation (Pires-Vanin \& Matsuura 1993; Meireles et al. 2006; Sant'Anna et al. 2009). However, such a rich scenario which depends on food availability is also subject to drastic environmental changes (Miranda et al. 2002).

It is important to keep in mind that phytoplankton biomass is considered a crucial factor for the distribution and abundance of several larval stages of shrimp (Thorson 1950). The match-mismatch theory proposed by Cushing (1975) attests that planktotrophic marine species tend to adjust their reproductive period to species with higher concentrations in ocean phytoplankton, reflected by a well concentrated 

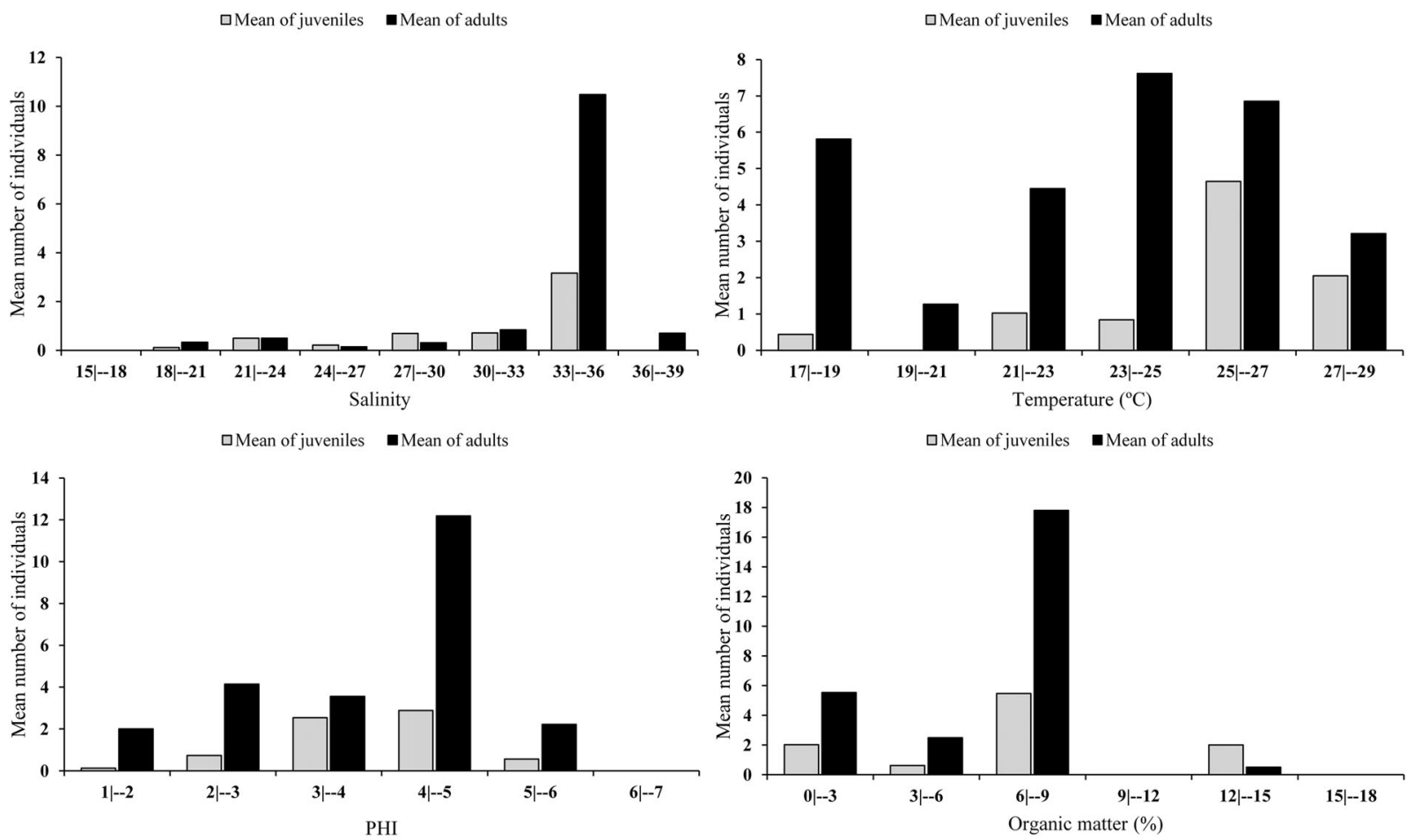

Figure 8. Abundance variation of adult and juvenile individuals of Litopenaeus schmitti between environmental classes standardized by the capture per unit of effort from data collected from July 2012 to May 2014 in the coastal area of Cananéia, São Paulo state.

reproductive period in subtropical regions. Therefore, crustaceans that use estuaries as nursery grounds (such as $P$. schmitti) can concentrate their reproductive activity in order to increase spawning success. As a

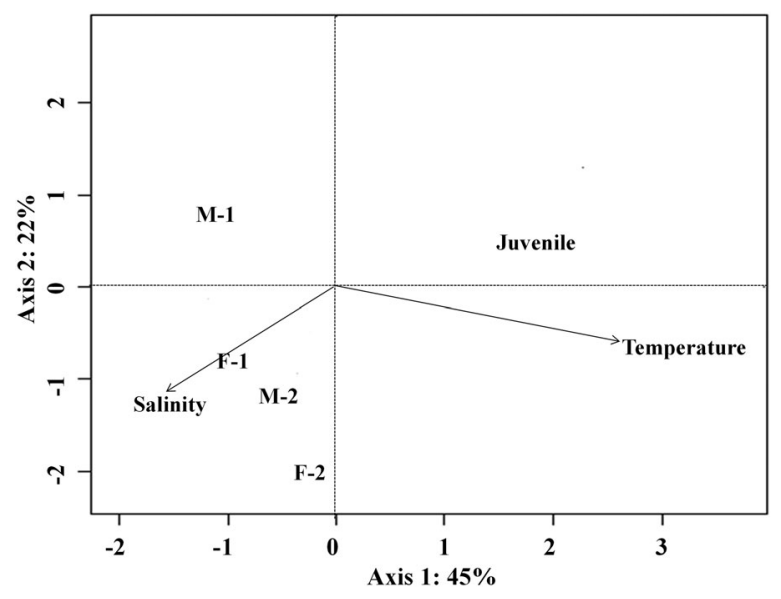

Figure 9. Canonical correspondence analysis between environmental variables (temperature, salinity, phi (measure of central tendency of the sediment) and organic matter) and the abundance of the demographic categories (juveniles, males with terminal ampoule in Stage I (M-1) and Stage II (M-2), females with ovaries in Stage I (F-1) and reproductive females (females with ovaries in Stages II and III grouped together, F2)) of Litopenaeus schmitti sampled from July 2012 to May 2014 in the coastal area of Cananéia, São Paulo state. consequence, this leads to an increase in the number of individuals in the subsequent season (summer), as observed in this study. On the other hand, the larger individuals sampled in autumn can be considered evidence for migratory activity taking place from shallower to deeper regions in order to complete the life cycle.

Neiva \& Jankauskis (1971) and Coelho \& Santos (1994) also found the same pattern of temporal distribution for $P$. schmitti, with higher numbers of juveniles in summer and an adult population captured in late autumn and the subsequent winter. This is beneficial for the population because it indicates that there is no competition between juveniles and adults for environmental resources, which can be an evolutionary adaptation of the species. However, it forces the species to depend on the presence of estuaries in its initial developmental stages, making it highly vulnerable to environmental impacts.

Such an abundance of juveniles, both inside the estuary and in the transition area between the estuary and the open sea, may be evidence for two different situations. First, it is possible that the capture of immature and developing individuals, which are associated with the smaller body sizes observed in the estuary, confirms the use of this environment as a nursery ground. Second, it is 
evidence of the physiological adjustment ability of these animals in the beginning of their ontogeny, since they are exposed to constant variation in the environmental factors (from the fresh water coming from continental sources and the tidal cycle, for instance). Here, we suggest that the migration of adult individuals is directly related to a decrease in their physiological tolerance, mainly concerning water salinity, since this factor had a large influence on the presence of adults. The coinciding increase in individual numbers with higher salinity means (33-36) was also observed for this species by Santos et al. (2008) and Bochini et al. (2014) in Ubatuba Bay.

In this study, $P$. schmitti was sampled at all sampling stations with an abundance peak in deeper areas $(15 \mathrm{~m})$. Such areas present a combination of two environmental factors biologically favourable to the presence of adult individuals (high water salinity and a predominance of fine and very fine sand in the substrate). This type of sediment allows for penaeid burrowing activity and presents an amount of organic matter content, providing the species protection against predators and an alternative food source (Costa et al. 2005, 2007; Santos et al. 2004).

Apart from the environmental features, fishing activities also have a direct impact on shrimp population dynamics. Therefore, fisheries regulations are applied to Brazilian fisheries in order to control fishing (maintaining ecologically sustainable stock levels and minimizing fishing impacts) and address socioeconomic issues (optimizing the use of these resources as an economic activity). Such rules refer to the restriction of fishing effort (limiting the issuing of fishing licences), the protection of areas (permanent closing of fishing areas) (Pérez et al. 2001; SEMA 2005), and a fishing closure period (prohibition of fishing activities). According to the normal instructions for Brazil \#189/2008, the fishing closure period varies according to the species and regions and is from 1 March to 31 May in southern and south-eastern Brazil; the main aim of the closure is to protect pink shrimp populations (Penaeus brasiliensis and $P$. paulensis). However, based on the recruitment period (observed in summer in this study) and a likely migratory movement in the subsequent season, it is possible to infer that the fisheries closure period also protects $P$. schmitti in the Cananéia region, reinforcing its efficacy. Similar results were found by Caparelli et al. (2012) in Ubatuba Bay, where the fisheries closure period also conferred protection to $P$. schmitti.
Furthermore, it is essential to consider estuarine environments and to establish specific laws and regulations for their protection. Our results emphasize the importance of the estuary of Cananéia for the initial stages of $P$. schmitti due to its life cycle complexity. In this environment, the species faces great exploitation pressure due to its use as live bait for fishing for Centropomus undecimalis (Bloch, 1792) and Cynoscion acoupa (Lacèpede, 1801), both of which are much appreciated by amateur fishermen in Cananéia. This leads to a significant correlation between high capture periods of both fish species and the period with high abundance of $P$. schmitti juveniles, since amateur fishermen are most active from January (before the closure period) to April (during the closure period) (Mendonça \& Katsuragawa 2001).

Therefore, the capture and utilization of juveniles from the estuarine environment results in a decrease in the abundance of individuals who can leave the estuaries and become adults that can be exploited by the fisheries, thus negatively affecting the region's economic situation. Consequently, we propose that the management of fishing resources from the estuarine-lagoon complex of Cananéia should include the initial stages of this species. It is important to remember that studies concerning shrimp species in southern and south-eastern Brazil usually report declining stocks due to overfishing, both in terms of adults and juveniles, in both coastal and estuarine zones (Valentini et al. 1991; D'Incao et al. 2002).

Our study provides an important theoretical base for current fishing management legislation and reinforces the need to protect shrimp resources, since they are targeted by both artisanal and industrial fisheries. Ecologically, it became evident that juveniles showed a great plasticity to environmental factors in contrast to adults, which showed a lower tolerance to such features as salinity, which limits their distribution. However, further studies concerning $P$. schmitti must be carried out in order to apply the biological knowledge obtained to the preservation of this species. It is also crucial to develop environmental educational programmes for the locals of Cananéia that aim to strengthen the relationships between people and nature. These actions are essential for the socioeconomic sustainability of shrimp fishing activities in Cananéia.

\section{Acknowledgements}

We thank many colleagues from the NEBECC group who helped with sampling and laboratory analyses; and the Instituto Brasileiro do Meio Ambiente e dos Recursos Naturais Renováveis (IBAMA) for granting permission to collect the shrimps. 


\section{Disclosure statement}

No potential conflict of interest was reported by the authors.

\section{Funding}

This work was supported by the FAPESP (Biota \#2010/50188-8 and Scholarship \#2015/07630-5), CAPES CIMAR (\#23038.004310/2014-85), and to CNPq (Financial Support \#406006/2012-1, Research scholarships PQ 305919/2014-8 and PQ 308653/2014-9).

\section{References}

Bauer RT, Lin J. 1994. Temporal patterns of reproduction and recruitment in populations of the penaeid shrimps Trachypenaeus similis (Smith) and T. constrictus (Stimpson) (Crustacea: Decapoda) form the north-central Gulf of Mexico. Journal of Experimental Marine Biology and Ecology 182:205-22. doi:10.1016/0022-0981(94)90052-3

Bauer RT, Rivera Vega LW. 1992. Pattern of reproduction and recruitment in two sicyoniid shrimp species (Decapoda: Penaeoidea) from a tropical seagrass habitat. Journal of Experimental Marine Biology and Ecology 161:223-40. doi:10.1016/0022-0981(92)90099-V

Bergamo AL. 2000. Características da Hidrografia, Circulação e Transporte de Sal: Barra de Cananéia, Sul do Mar de Cananéia e Baía de Trapandé. Doctoral Thesis. Universidade de São Paulo, Brazil: Instituto Oceanográfico. 254 pages.

Besnard W. 1950. Considerações gerais em tôrno da região lagunar de Cananéia-Iguape: I. Boletim do Instituto Paulista de Oceanografia 1(1):9-26. doi:10.1590/S010042391950000100003

Bochini GL, Franzoso A, Castilho AL, Hirose GL, Costa RC. 2014. Temporal and spatial distribution of the commercial shrimp Litopenaeus schmitti (Dendrobranchiata: Penaeidae) in the south-eastern Brazilian coast. Journal of the Marine Biological Association of the United Kingdom 94(5):1001-08. doi:10.1017/S0025315414000265

Boschi EE. 1989. Biologia pesquera del langostino del litoral patagônico de Argentina (Pleoticus muelleri). Serie Contribuciones del INIDEP 646:1-71.

Capparelli MV, Kasten P, Castilho AL, Costa RC. 2012. Ecological distribution of the shrimp Litopenaeus schmitti (Burkenroad, 1936) (Decapoda: Penaeoidea) in Ubatuba bay, São Paulo, Brazil. Invertebrate Reproduction and Development 56:173-79. doi:10.1080/07924259.2011. 587272

Castilho AL, Costa RC, Fransozo A, Negreiros-Fransozo ML. 2008. Reproduction and recruitment of the South American red shrimp, Pleoticus muelleri (Crustacea: Solenoceridae), from the southeastern coast of Brazil. Marine Biology Research 4(5):361-68. doi:10.1080/ 17451000802029536

Castilho AL, Bauer RT, Freire FAM, Franzoso V, Costa RC, Grabowski RC, Fransozo A. 2015a. Lifespan and reproductive dynamics of the commercially important sea bob shrimp Xiphopenaeus kroyeri (Penaeoidea): synthesis of a 5-year study. Journal of Crustacean Biology 35(1):30-40. doi:10.1163/1937240X-00002300
Castilho AL, Grabowski RC, Simões SM, Santos APF, Costa RC, Fransozo A. 2015b. Lifespan and population dynamics of the endemic South American shrimp Artemesia longinaris (Crustacea: Penaeidae) in southeastern Brazil. Anais da Academia Brasileira de Ciências 87:2123-2138. doi:10. 1590/0001-3765201520140698

Chagas-Soares F, Pereira OM, Santos EP. 1995. Contribuição ao ciclo biológico de Penaeus schmitti Burkenroad, 1936, Penaeus brasiliensis Latreille, 1817, Penaeus paulensis Pérez-Farfante, 1967, na região lagunar-estuarina de Cananéia, São Paulo, Brasil. Boletim do Instituto de Pesca 22(1):49-59.

Coelho PA, Santos MCF. 1994. Ciclo biológico de Penaeus schmitti Burkenroad em Pernambuco (Crustacea, Decapoda, Penaeidae). Boletim Técnico Científico CEPENE 2(1):35-50.

Costa RC, Fransozo A. 2004. Reproductive biology of the shrimp Rimapenaeus constrictus (Decapoda, Penaeidae) in the Ubatuba region of Brazil. Journal of Crustacean Biology 24:274-81. doi:10.1651/C-2437

Costa RC, Fransozo A, Melo GAS, Freire FAM. 2003. An illustrated key for Dendrobranchiata shrimps from the northern coast of São Paulo state, Brazil. Biota Neotropica 3(1):1-12. doi:10.1590/S1676-06032003000100011

Costa RC, Fransozo A, Castilho AL, Freire FAM. 2005. Annual, seasonal and spatial variation of abundance of the shrimp Artemesia longinaris (Decapoda: Penaeidae) in south-eastern Brazil. Journal of the Marine Biological Association of the United Kingdom 85:107-12. doi:10. 1017/S0025315405010908h

Costa RC, Fransozo A, Freire FAM, Castilho AL. 2007. Abundance and ecological distribution of the 'setebarbas' shrimp Xiphopenaeus kroyeri (Heller, 1862) (Decapoda, Penaeoidea) in three bays of the Ubatuba region, southeastern Brazil. Gulf and Caribbean Research 19:33-41. doi:10.18785/gcr.1901.04

Cushing DH. 1975. Marine Ecology and Fisheries. Cambridge: Cambridge University Press. 278 pages.

Dall W, Hill BJ, Rothlisberg PC, Staples DJ. 1990. The biology of the Penaeidae. Advances in Marine Biology 27:1-489.

Diegues ACS. 1987. Conservação e desenvolvimento sustentado de ecossistemas litorâneos no Brasil. In: Simpósio sobre Ecosistemas da Costa Sul e Sudeste Brasileira: Sintese dos Conhecimentos. Sao Paulo: Secretaria do Meio Ambiente de São Paulo, p 196-243.

Diegues ACS. 2002. Povos e Águas: Inventário de Áreas Úmidas Brasileiras. São Paulo: NUPAUB. 597 pages.

D'Incao F, Valentini H, Rodrigues LF. 2002. Avaliação da pesca de camarões nas regiões sudeste e sul do Brasil 1965-1999. Atlântica 24(2):103-16.

Dura MFR. 1985. El ciclo biológico de los camarones peneidos. Técnica Pesquera 5:12-15.

Garcia JR, Wolf MR, Costa RC, Castilho AL. 2016. Growth and reproduction of the shrimp Rimapenaeus constrictus (Decapoda: Penaeidae) from the southeastern coast of Brazil. Regional Studies in Marine Science 6:1-9. doi:10. 1016/j.rsma.2016.02.006

Hakanson L, Jansson M. 1983. Lake Sedimentology. Berlin: Springer. 316 pages.

Hartnoll RG. 2001. Growth in Crustacea - twenty years on. Hydrobiologia 449:111-22. doi:10.1023/A:1017597104367 
Kutner MBB. 1972. Variação Estacional e Distribuição do Fitoplâncton na Região de Cananéia. Doctoral Thesis. Universidade Estadual de São Paulo, Brazil. 107 pages.

Matsuura Y. 1986. Contribuição ao estudo da estrutura oceanográfica da região sudeste entre Cabo Frio (RJ) e Cabo de Santa Marta Grande (SC). Ciência e Cultura 38 (8):1439-50.

Meireles AL, Terossi M, Biagi R, Mantelatto FLM. 2006. Spatial and seasonal distribution of the hermit crab Pagurus exilis (Benedict, 1892) (Decapoda: Paguridae) in the southwestern coast of Brazil. Revista de Biología Marina y Oceanografía 41:87-95.

Mendonça JT. 2007. Gestão de Recursos Pesqueiros do Complexo Estuarino-Lagunar de Cananéia-Iguape-Ilha Comprida, Litoral Sul de São Paulo. Doctoral Thesis. Universidade Federal de São Carlos, Brazil. 383 pages.

Mendonça JT. 2015. Caracterização da pesca artesanal no litoral sul de São Paulo - Brasil. Boletim do Instituto de Pesca 41(3):479-92.

Mendonça JT, Katsuragawa M. 2001. Caracterização da pesca artesanal no complexo estuarino-lagunar de CananéiaIguape, Estado de São Paulo, Brasil (1995-1996). Acta Scientiarum Maringá 23(2):535-47.

Miranda LB, Castro BM, Kjerfve B. 2002. Princípios de Oceanografia Física de Estuários. São Paulo: Editora da Universidade de São Paulo. 424 pages.

Nakagaki JM, Negreiros-Fransozo ML. 1998. Population biology of Xiphopenaeus kroyeri (Heller, 1862) (Decapoda: Penaeidae) from Ubatuba Bay, São Paulo, Brazil. Journal of Shellfish Research 17:931-35.

Neiva GS, Jankauskis V. 1971. Análise preliminar da população de camarão-legítimo Penaeus schmitti Bunkenroad, 1936, na Baía de Santos - Brasil. Boletim do Instituto de Pesca 1(2):7-14.

Pauly D, Christensen V, Guénette S, Pitcher TJ, Sumaila U, Walters C, et al. 2002. Towards sustainability in world fisheries. Nature 418:689-95. doi:10.1038/nature01017

Pérez JAA, Pezzuto PR, Rodrigues LF, Valentini H, Vooren CM. 2001. Relatório da reunião técnica de ordenamento da pesca de arrasto nas regiões sudeste e sul do Brasil. Notas técnicas FACIMAR 5:1-34.

Pires-Vanin AMS, Matsuura Y. 1993. Estrutura e função do ecossistema de plataforma continental da região de Ubatuba, estado de São Paulo: uma introdução. Publicação Especial do Instituto Oceanográfico 10:1-8.

R Development Core Team. 2008. R: A Language and Environment for Statistical Computing. Vienna: $R$ Foundation for Statistical Computing. http://www.Rproject.org. Computer program.
Sanchez AJ. 1997. Habitat preference of Penaeus duorarum Burkenroad (Crustacea: Decapoda) in a tropical coastal lagoon, southwest Gulf of Mexico. Journal of Experimental Marine Biology and Ecology 217:107-17. doi:10.1016/S0022-0981(97)00049-X

Sant'Anna BS, Reigada ALD, Pinheiro MAA. 2009. Population biology and reproduction of the hermit crab Clibanarius vittatus (Decapoda: Anomura) in an estuarine region of southern Brazil. Journal of the Marine Biological Association of the United Kingdom 89(4):761-67. doi:10. 1017/S0025315409003075

Santos JL, Severino-Rodrigues E, Vaz-Dos-Santos AM. 2008. Estrutura populacional do camarão-branco Litopenaeus schmitti (Burkenroad, 1936) nas regiões estuarinas e marinhas da Baixada Santista, São Paulo, Brasil. Boletim do Instituto de Pesca 34(3):375-89.

Santos MCF, Pereira JA, Ivo CTC. 2004. Sinopse de informações sobre a biologia e pesca do camarão-branco, Litopenaeus schmitti (Burkenroad, 1936) (Crustacea, Decapoda, Penaeidae), no nordeste do Brasil. Boletim Técnico Científico CEPENE 12(1):149-85.

SEMA. 2005. Zoneamento Ecológico-Econômico - Litoral Norte São Paulo. Secretaria de Estado do Meio Ambiente. Coordenadoria de Planejamento Ambiental Estratégico e Educação Ambiental. São Paulo: SMA/ CPLEA. 55 pages.

Stanley SM. 1984. Temperature and biotic crises in the marine realm. Geology 12:205-08. doi:10.1130/0091-7613(1984) $12<205:$ TABCIT>2.0.CO;2

Suguio K. 1973. Introdução à Sedimentologia. São Paulo: Edgard Blücher/EDUSP. 317 pages.

Ter Braak CJF. 1986. Canonical correspondence analysis: a new eigenvector technique for multivariate direct gradient analysis. Ecology 67(5):1167-79. doi:10.2307/ 1938672

Thorson G. 1950. Reproductive and larval ecology of marine bottom invertebrates. Biological Reviews 25(1):1-45. doi:10.1111/j.1469-185X.1950.tb00585.x

Tucker M. 1988. Techniques in Sedimentology. Oxford: Blackwell. 394 pages.

Valentini H, D'Incao F, Rodrigues LF, Rebelo Neto JE, Rahn E. 1991. Análise da pesca do camarão-rosa (Penaeus brasiliensis e Penaeus paulensis) nas regioes sudeste e sul do Brasil. Atlântica 13(1):143-57.

Wentworth CK. 1922. A scale of grade and class terms for clastic sediments. The Journal of Geology 30:377-92. doi:10.1086/622910

Zar JH. 1999. Biostatistical Analysis. Upper Saddle River, NJ: Prentice Hall. 663 pages. 